\title{
Foreword from the editors of this volume: On crossing perspectives
}

If the reader slowly takes his pleasure on the process of reading by stopping, relaxed and nonchalant, on every single contribution to appreciate its specificity, he may be pleasantly confused by the richness and variety of figures and issues, themes and questions approached in this collective volume: Paul Rabinow, Eric Wolf, Clifford Geertz, Bronislaw Malinowski, Claude Lévi-Strauss, Robert Antelme, Victor Klemperer, Geneviève De Gaulle Anthonioz, Jorge Semprun, Jean Geoffroy, Juri Vella, anthropologists' diaries, survivors' diaries, the nature/culture distinction, colonial memory, Estonian events in the 40 s, theatre representation, and so on. Studies on less known figures of camp survivors stand side by side with studies on renowned anthropologists, anthropologic reflections on cultural matters alternate with semiotic analyses of literary texts. What is the leading thread bringing into a unitary path such variety and abundance, such apparent diversity?

In 2006, June 2-3, we organized at the French section of studies of the Department of German and Romance Languages, in collaboration with the Department of Semiotics of the University of Tartu, an international conference "Between Semiotics and Anthropology. Crossed Perspectives on Signs and Cultures", ${ }^{1}$ whose main idea was essentially to bring together various anthropologists and semioticians, different specialists of camp literature and life histories to discuss specific problems such as the interrelation existing between signs and cultures and the parallel question of experience and its transformation into a narration. As a consequence, 'signs' and 'cultures', 'experience'

\footnotetext{
1 In French: "Entre sémiotique et anthropologie. Questionnements croisés sur les signes et les cultures"; in Estonian: "Semiootika ja antropoloogia kokkupuutes. Kõrvutavaid arutlusi märkide ja kultuuride üle". As an exception for Sign Systems Studies, we publish five articles in this volume in French.
} 
and 'narration' are the crucial axes around which revolve the contributions collected in this volume. They convey, along with essential results in single disciplines, the open-minded atmosphere reigning during the conference and the effort of crossing perspectives manifested by all participants.

More exactly, what the different essays share is the (amazing and always difficult to define) (i) passage from a single sign to a more global and pervasive culture and the (ii) generation of a concrete narration from a fluid and volatile experience originally situated in a specific time and space. If the general and recurrent question posited concerns the definition of signs and cultures, here the focus is laid more on the epistemological foundations of methodologies, on the comparisons of approaches and interpretations of processes. The basic presupposition and aim of the conference was in effect to let disciplinary theories and practices interact in order to see, in this fruitful exchange, how to enrich one another, how to go over internal discursive boundaries and hermeneutical positions. More than a simple international conference, it could be said that Tartu, on the 2nd and the 3rd of June 2006, became a meeting place for anthropologists and semioticians to question each other on their respective disciplines, on the possibilities and potentialities these disciplines possess, on the goals they presuppose in order to seize reality and social interactions. The conference foresaw two complementary sections: a first and freer section on anthropologic and semiotic issues where participants could intervene by choosing their subjects and a second and more specific section concerning survival life histories originating in France and Estonia. This parallel may seem somewhat strange to readers. What do survival life histories have to do with epistemological foundations of disciplines such as anthropology and semiotics?

The first answer is that even if different under some aspects, above all for the evident consequences and tremendous impact on personal lives, both anthropologists and survivors draw on their experience to transform it into a real and true story codified, implicitly or explicitly, through semiotic strategies. The second answer is that the extreme experience lived by survivors calls for a redefinition of culture and humanity and this concept, improved, neglected, redefined, either assumed sceptically or optimistically, is the main theme upon which anthropologists base their work. Any school of thought in anthropology strives for defining, overtly or implicitly, culture and humanity 
in a way that is every time more comprehensive and total, more corresponding to modern life and to global world. Conversely, theoretical problems raised by anthropologists and semoticians, such as definitions of concepts and 'seizures' of objects of knowledge, are practically encountered in extreme life conditions by survivors. In short, survivors do a work comparable to the work of anthropologists and semioticians because they try to redefine humanity after a terrible event such as, for example, the Holocaust; they use condensed semiotic elements in their writing; they catch experience through effective signs.

In addition, it is not to be forgotten that survivors tell their experiences, and very often their perplexity towards a positive sense of humanity, by resorting to a written 'translation' of an experience lived in concentration camps, an experience that tends to become a real and true literary genre, that is a literature of its own. By using the term 'genre', nobody wants to affirm that what was lived by survivors was false or invented, but that, once in a written form, an experience is inevitably codified and based on a narrative structure. Contributors of this collective volume explore the most recurrent or unusual narrative structures used by survivors in their texts and the way survivors catch glimpses of phenomenological experiences. Besides it, this issue raises another important point and parallel with anthropologists and semioticians. What is the threshold between the 'literary' and the 'non-literary', between what is considered as 'fiction' and what is considered as 'experience'?

When an anthropologist goes to an exotic place (and even when he stays at home, in his own culture), he needs to live Otherness concretely in his own experience and, eventually, he has to transform himself into a writer, a translator for his 'departure culture'. In other words, an anthropologist is a witness who has to prove his own truth, an individual who adapts himself to the 'Other', a translator and a writer. For a survivor, all these roles are filled by risking his life and against his will. Sometimes more than an anthropologist, a survivor has to find new ways to utter an extreme experience, new ways which disrupt received distinctions and concepts such as, for example, 'fiction', 'literary', 'realistic', 'invented', 'testimony', 'experienced', and so on. This aspect is taken into account in this collective volume both from anthropological and semiotic viewpoints. 
In this perspective, camp literature is also extremely interesting to investigate because it amplifies some fundamental dichotomies inscribed in our texts and cultures: (i) the external referent and the internal narrative organization; (ii) the mimetic truth and the narrative structure; (iii) the reality and convention opposition; (iv) the difference between experience and its codification; (v) the nature and culture distinction. In one way or another, survival life histories combine these oppositions in a new manner. In the new light shed by camp literature, the study of these features is pertinent both for semiotics and anthropology. If, then, semiotic modalities through which these events are caught are important for history and man in itself, it is also central to investigate the ways through which these forms of humanities and non-humanities are conceived, imposed, tolerated, reinvented. All the contributions in this collective volume, in one way or another, take into account some directions leading to the better understanding of these central (op)positions present in our culture or in single authors, in anthropology or in semiotics.

More specifically, in this issue one can find a semiotic reflection on the epistemological foundations of some anthropologic theories (Peeter Torop, Eric Landowski, Irene Portis-Winner, Stefano Montes, Art Leete and Piret Koosa) or a reflection on some disciplinary fields and distinctions (Elena Moratidou). At the same time, one can also find an anthropologic viewpoint on central concepts in semiotics (Richard Pottier). In addition, as already explained, some contributions study life histories (Gabriella D'Agostino, Eva Toulouze and Liivo Niglas) and deportation and camp literature (Licia Taverna, Luba Jurgenson, Michael Rinn, Tiiu Jaago). ${ }^{2}$

Licia Taverna $^{3}$
Stefano Montes

2 Acknowledgements. Along with all participants we would also like to mention and thank Kalevi Kull for his enthusiasm and collaboration. This issue received support from the Estonian Scientific Foundation (ETF Grant 6791) whose related research is "Semiotics of Histories of Survival. A Comparative Perspective on France and Estonia" ("Ellujäämislugude semiootika. Eesti ja prantsuse võrdlev käsitlus").

${ }^{3}$ Author's address: Department of French Studies, University of Tartu, Ülikooli Str. 17, 50090 Tartu, Estonia; e-mail: licia.taverna@tiscalinet.it.

4 Author's address: Department of French Studies, University of Tartu, Ülikooli Str. 17, 50090 Tartu, Estonia; e-mail: montes.stefano@tiscalinet.it. 